\title{
Konsep Taman Edukasi pada Sekolah Dasar di Kota Malang (Studi Kasus: SDN Lowokwaru 3 Malang)
}

\author{
Irawan Setyabudi ${ }^{1}$, Nuraini' ${ }^{2}$, Rizki Alfian ${ }^{3}$, Balqis Nailufar $^{4}$ \\ 1,2,3,4 PS. Arsitektur Lanskap Fakultas Pertanian Universitas Tribhuwana Tunggadewi \\ Email : isetyabudi.st@gmail.com
}

\begin{abstract}
ABSTRAK
Pekarangan merupakan ruang terbuka yang mempunyai potensi untuk dikembangkan sebagai area taman dan perkerasan, namun demikian banyak diantaranya yang berpikir bahwa pekarangan hanya lahan sisa dan pemanfaatannya hanya sekedarnya dari bangunan di sekitarnya. Kajian difokuskan pada pekarangan sekolah dengan bangunan utama berfungsi sebagai edukasi. Umumnya siswa belajar di dalam kelas hingga usai menerima pelajaran, hal tersebut terkadang mengakibatkan tekanan psikologis kepada siswa seperti stres yang berdampak pada hasil belajar. Salah satu fungsi healing secara arsitektural adalah penyediaan taman yang didesain secara fungsional dan estetis. Penelitian diawali dengan Focus Group Discussion (FGD) dengan komite sekolah SD Lowokwaru 3 Malang yang membahas kebutuhan rancangan taman. Taman tersebut terbagi atas zona-zona tertentu seperti zona taman estetika, produktif, dan vertikal dengan teknologi sederhana. Taman tidak hanya sekedar taman pasif atau hanya dikonsumsi secara visual, tetapi siswa bisa juga dilibatkan langsung tentang proses pembuatan, perawatan dan pengelolaannya. Tujuan penelitian ini adalah memberikan alternatif rancangan model taman yang bersifat rekreatif dan edukatif bagi siswa, sedangkan target khususnya adalah mengkaji permasalahan pada taman sekolah, menganalisis, dan menghasilkan konsep taman edukasi. Metode penelitian dilakukan secara kualitatif dengan desain arsitektur yang berakhir pada konsep, dengan alur pemikiran dari Gold dan Rustam Hakim, disesuaikan terhadap ilmu pertanian dan pendidikan. Hasil penelitian berupa pembagian zonasi ruang taman berdasarkan ruang edukasi dan bermain dalam konsep rancangan arsitektur beserta pemilihan vegetasinya. Kesimpulannya adalah taman dapat sebagai sarana edukasi ruang luar bagi siswa sekolah.
\end{abstract}

Kata kunci : pekarangan, konsep taman, rekreatif-edukatif, dan pembelajaran luar kelas

\section{ABSTRACT}

The yard is an open space that has potential to be developed as a garden area and pavement, but many people think garden is only a waste land that utilization and modest from the surrounding buildings. The study focused on the school yard with the main building serving as education. Generally students learn in the classroom until after receiving lessons, it sometimes leads to psychological pressure to students such as stress that impact on learning outcomes. One of the architectural healing functions is the provision of a functionally and aesthetically designed garden. The research started with Focus Group Discussion (FGD) with school committee of SD Lowokwaru 3 Malang which discussed the need of garden design. The garden is divided into certain zones such as esthetic, productive, and vertical garden zone with simple technology. The garden is not only a passive garden or consumed visually, but students can also be involved directly about the process of making, maintaining and managing it. The purpose of this research is to provide alternative model of recreational and educational garden design for students, while the specific target is to study problems in school garden, analyze, and produce educational garden concept. The research method is conducted qualitatively with architectural design which ends on the concept and follow Gold and Rustam Hakim's thinking, with adjustment to agricultural science and education. The result of the research is the division of zoning of garden space based on educational space and playing in the concept of architectural design along with the selection of vegetation. The conclusion of this research is the garden as outdoor education facility for school students.

Keywords: garden, concept, recreative-educative, and outdoor learning

\section{Pendahuluan}

Pekarangan seringkali mengalami penyempitan makna karena hanya berupa ruang terbuka yang fungsinya sekedarnya, seperti lahan kosong sisa dari bangunan di sekitarnya. Menurut Permen PU No 05/PRT/M/2008, memiliki definisi lahan di luar 
bangunan yang berfungsi untuk aktivitas, di dalamnya terdapat ruang terbuka hijau yang terdiri atas pohon peneduh atau pelindung, semak, perdu dan penutup tanah yang dikategorikan berdasarkan luasannya. Batasan pekarangan pada artikel ini ditujukan pada ruang terbuka pada sekolah. Para peneliti sebelumnya telah mengkaji bahwa fungsi pekarangan khususnya pada area sekolah adalah sebagai berikut.

Menurut Baskara (2011), manusia selalu melakukan kegiatan bermain pada masa anak-anak, dikarenakan mampu membangkitkan sisi kognitif, sosial, fisik, serta kemampuan emosional yang dibutuhkan pada saat dewasa. Aktivitas tersebut membutuhkan suatu wadah berupa ruang terbuka yang bersifat publik atau taman. Upaya penyediaan taman dengan fasilitas yang baik telah menjadi kesadaran pada negara maju, namun tidak demikian bagi negara berkembang. Eksistensinya masih terkesan sebagai pelengkap bangunan. Pada bangunan sekolah, rancangan taman yang tidak melibatkan tenaga ahli, tidak tertata rapi, jumlah variasi tanaman terlalu banyak dan bahkan terkadang berbahaya. Selain pengembangan softscape-nya juga pada hardscapenya. Penyediaan fasilitas bermain yang salah secara desain ataupun pemeliharaan yang kurang dapat memicu resiko kecelakaan.

Menurut Lauren (2012), ruang terbuka atau taman seringkali dimanfaatkan sebagai taman bermain anak dengan fasilitas pendukungnya. Selain aktivitas rekreatif juga perlu dikembangkan aspek edukatif, karena usia anak yang masih muda dan peka terhadap rangsangan yang berasal dari lingkungan. Berdasarkan perilakunya, anak sekarang cenderung bermain gadget dan kurang peka terhadap perubahan lingkungannya, sehingga perlu dikembangkan suatu taman yang edukatif dan menarik untuk anak-anak.

Aspek edukasi, Ramadhani (2016) menyebutkan bahwa salah satu bentuk pembelajaran adalah memberikan pengalaman secara langsung, sehingga siswa dapat memahami konsep yang sedang dipelajari. Pada saat mata pelajaran Ilmu Pengetahuan Alam (IPA), guru dapat memberikan kegiatan pembelajaran Outdoor Learning Process (OLP) yaitu memanfaatkan taman sebagai media untuk memahami karakter tumbuhan. Kegiatan ini sebenarnya cukup sulit karena merepotkan guru dan dalam pelaksanaannya harus sesuai dengan waktu pembelajaran, namun dengan perancangan taman yang baik siswa dapat belajar secara langsung mengenai fenomena alam sehingga proses pembelajaran lebih bermakna.

Azra (2013), juga menambahkan bahwa suatu konsep pekarangan dapat menunjang keanekaragaman pangan. Fungsi ini merupakan upaya dari pemilik pekarangan untuk memperoleh manfaat eksistensinya, mulai dari estetika tanaman hias, manfaat perolehan pangan dari tanaman obat, sayur, buah, dan penghasil pati. Manfaat tambahan dari tanaman bumbu dapur dan tanaman obat keluarga (TOGA). Wujudnya bisa dikembangkan secara horizontal ataupun vertikal tergantung dari luasan pekarangan tersebut. Pekarangan dengan sistem vertikal bisa dilakukan dengan vertikultur. Asikin et.al (2016) menyebutkan bahwa taman vertikal sebagai elemen arsitektur sebagai pembatas gerak pandangan, penutup dan penghias dinding, pengarah, pembatas visual dan elemen estetis.

Berdasarkan aspek kajian penting tersebut, peneliti yang sejak awal akan merancang suatu taman yang memberikan nilai edukasi kepada siswa, melakukan diskusi dengan para anggota komite sekolah. Fokus penelitian adalah ruang terbuka di SD Lowokwaru 3 Malang dengan eksisting sebagai berikut. Secara garis besar taman sudah dikembangkan menarik oleh internal sekolah, namun permasalahannya adalah kurang rapi atau tertata, tidak ada pembagian zona; hanya ada taman yang berfungsi sebagai estetika, jumlah variasi tanaman terlalu banyak pada satu tempat sehingga terkesan kabur, serta penggunaan pot yang ala kadarnya. Focus Group Discussion (FGD) yang 
dilakukan menghasilkan penataan ulang taman pada sekolah dengan arahan konsep yang lebih matang, sehingga permasalahan utamanya adalah 'bagaimana konsep perancangan taman edukasi pada sekolah dasar khususnya SD Lowokwaru 3 Kota Malang?' Penelitian ini bertujuan untuk membuat konsep taman edukasi bagi siswa sekolah, khususnya di SD Lowokwaru 3 sebagai bentuk dari pengabdian kepada masyarakat.

\section{Bahan dan Metode}

\subsection{Bahan Kajian Literatur}

\section{a. Rancangan Taman}

Rancangan atau desain merupakan suatu proses kreatif yang mengolah potensi lahan dan penyesuaian kebutuhan sehingga mewujudkan suatu rencana yang siap diaplikasikan. Menurut Hakim (2002) dan Setyabudi (2016), prosesnya diawali dari inventarisasi/observasi/pencatatan data yang ada di lapangan, dilanjutkan dengan studi banding dari literatur dan preseden tentang objek studi sebelumnya. Proses berikutnya adalah inti dari analisis-sintesis yang mengkaji potensi tapak, kebutuhan pengguna dan penentuan fungsi ruang yang besarannya dihitung kuantitatif maupun kualitatif. Output dari desain berupa gambar kerja, poster, maket ataupun visualisasi yang siap dikomunikasikan kepada klien.

Rancangan taman khususnya pekarangan mewadahi aktivitas bermain anak sekolah, yang mana Baskara (2011) dan Lauren (2012) menyebutkan bahwa bermain dilakukan dengan bebas untuk memperoleh keriangan, kesenangan, dan kegembiraan serta sebagai sarana untuk mengembangkan kemampuan kognitif, sosial, fisik dan kemampuan emosinya. Tidak harus hadir dengan semua permainan, namun kondisi mengacu pada keselamatan.

\section{b. Taman Edukatif}

Lauren (2012) juga menyebutkan bahwa masa anak-anak terakhir pada usia sekolah dasar antara 6-13 tahun, yang mana proses sosialisasi telah berlangsung secara efektif, masa persiapan menuju dewasa. Menurut Mandagi (2013), taman edukatif merupakan sarana bagi anak sekolah untuk memiliki rasa ingin tahu yang tinggi tentang keilmuan atau sains sehingga tertarik untuk mempelajarinya. Dasar taman edukatif adalah bermain. Anak dibiarkan bermain, namun pada akhirnya juga belajar sains. Taman edukatif bisa diberikan saat variasi pelajaran formal ataupun suplemen jika bukan pada pelajaran formal.

Kriteria konsep taman edukatif menurut Mandagi (2013) sebagai berikut :

(1) Adanya ruang edukasi, yang terdiri atas area observasi untuk memberikan edukasi mengenai ragam jenis vegetasi maupun satwa kepada anak-anak. Area ini termasuk kegiatan pasif karena pengunjung hanya berjalan dan mengamati.

(2) Penggunaan elemen keras dan lunak. Elemen keras pada anak-anak menggunakan material dari alam atau menyerupai alam, seperti kayu dan batubatuan. Adaptasi dari alam menciptakan kesan alami dan selaras dengan lingkungan. Utamanya pemilihan material tidak beracun dan aman bagi anakanak. Elemen lunak digunakan tanaman berdasarkan fungsi vegetasi, baik sebagai peneduh, pembatas ataupun estetis. Vegetasi peneduh bertajuk payung seperti ketapang, pembatas contohnya semak penitian, sedangkan estetis seperti tanaman berbunga atau berdaun indah.

(3) Adanya ruang bermain, meliputi permainan fisik, kreatif, sosial dan indera. Ada permainan yang diakomodasi dalam suatu taman yaitu permainan fisik, kreatif, sosial, indera dan ketenangan. Tipe permainan ini bersifat edukatif karena mengajarkan anak agar berkembang, seperti halnya permainan fisik yang 
menuntut selalu aktif merangsang motorik; taman kreatif yang merangsang daya imajinasi; taman sosial yang merangsang anak-anak beradaptasi dengan teman sebayanya menurut mereka sendiri; taman indera yang menstimulasi indera peraba, pendengaran, penglihatan, penciuman dan memperkaya pengalaman; serta permainan ketenangan yang menyediakan area untuk istirahat yang bersifat menenangkan.

c. Konsep Urban Farming pada Pekarangan

Pekarangan selain digunakan sebagai taman edukasi juga menunjang fungsinya sebagai bentuk dari urban farming. Konsepnya berasal dari upaya memindahkan pertanian dari desa ke kota atau ketahanan pangan mandiri. Keragaman warna pangan dapat mencerminkan gizi yang diperoleh. Hal ini karena warna tanaman dapat mencerminkan senyawa fitokimia, sehingga semakin beragam warna tanaman maka zat gizi semakin banyak (Azra, 2013). Kebutuhan urban farming masih sekunder dan menggunakan media vertikultur. Adapun tanamannya tidak berzat kayu dan tidak berat, didominasi oleh sayuran berwarna hijau, seperti selada hijau, seledri, sawi, caisin, pokcoy dan kangkung.

\subsection{Metode Penelitian}

Metode analisis pada penelitian ini dengan pendekatan deskriptif kualitatif secara eksploratif menganut pemikiran Gold (1980) dan Hakim (2012) yang dikuatkan oleh Setyabudi (2016), yang menjelaskan bahwa metode perancangan arsitektur terdiri atas (1) penetapan proyek, (2) studi objek, (3) inventarisasi tapak, (4) programming, (5) konsep, (6) masterplan/pradesain, (7) pengembangan desain, dan (8) komunikasi arsitektur. Artikel penelitian ini dibatasi dari tahapan programming hingga konsep saja. Adapun alat untuk analisis data digunakan software grafis komputer berupa SketchUp 2017 dan Lumion Pro 6.

Metode pengumpulan data diawali dengan mencari data primer dan sekunder. Data primer berupa data fisik lokasi (foto, hasil ukur dan sketsa), data hasil wawancara dengan pengurus komite sekolah, serta pemetaan lokasi. Data didapatkan dari inventarisasi lapangan dengan alat kamera, alat tulis dan alat rekam. Kegunaan data untuk analisis kualitatif yaitu potensi dan kendala tapak, analisis fungsi dan kebutuhan, dan analisis objek. Data sekunder berupa studi preseden terhadap taman edukasi sejenis, yaitu taman edukasi lingkungan di Situ Cikaret dan taman lingkungan anak sekolah dasar di Cluster Callysta Permata di Tangerang Selatan. Lokasi dipilih di SD Lowokwaru 3 Malang karena adanya kerjasama antara Program Studi Arsitektur Lanskap Unitri dan pihak sekolah dalam bentuk pengabdian masyarakat, hal ini untuk memberikan alternatif rancang bangun taman yang sesuai dengan visi dan misi sekolah. Waktu penelitian dikerjakan pada bulan Maret 2017 dan berakhir bulan April 2017. Berikut adalah gambar lokasi dan objek penelitian.

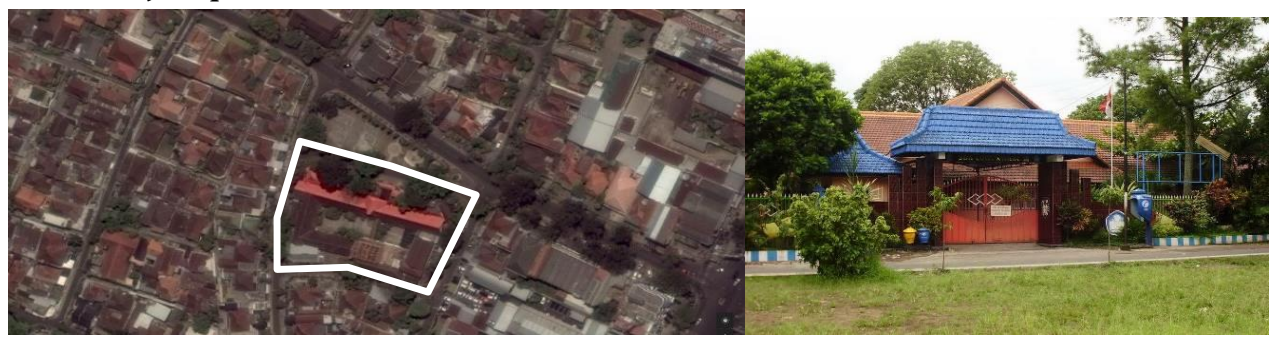

Gambar 1. (kiri) Peta Lokasi dan (kanan) Foto Depan SDN Lowokwaru 3 (sumber: googlemaps, 2017) 


\section{Hasil dan Diskusi}

a. Kondisi Eksisting Tapak

Sekolah dasar sebagai studi kasus pada penelitian ini adalah SDN Lowokwaru 3, terletak di Jalan Sarangan No 1 Malang. Sekolah ini didirikan tahun 1945 dan beroperasi hingga sekarang dengan status tanah milik pemda. Jumlah siswa dalam tiga tahun terakhir dengan rata-rata 650 siswa yang terbagi atas 3 rombongan belajar mulai kelas 1-5 dan 4 rombongan belajar untuk kelas 6 . Ruang terbuka pada sekolah ini terbagi atas 3 tempat yaitu taman depan, taman tengah dan taman belakang. Gedung sekolah bagian depan terdiri atas ruang kelas $1 \mathrm{~A}, 1 \mathrm{~B}, 1 \mathrm{C}, 2 \mathrm{~A}, 6 \mathrm{~A}, 6 \mathrm{~B}, 6 \mathrm{C}, 6 \mathrm{D}$ dan ruang kantor, bagian gedung kanan untuk kelas 5A, 5B, dan 5C, bagian gedung kiri untuk kelas 2B, 2C, dan UKS, sedangkan bagian belakang kelas 4A, 4B, 4C, koperasi, labkom, perpustakaan, gudang, dan kamar kecil. Semua gedung memusat pada taman tengah yang dihubungkan dengan jalan. Untuk ruang kelas yang belum tercantum, ada pada lantai 2. Taman juga berada di depan sekolah dan masjid. Sebelumnya telah disinggung bahwa diskusi grup/Focus Discussion Group (FGD) dengan komite sekolah untuk merumuskan suatu taman yang menjawab permasalahan taman yaitu teratur, rapi, estetis, produktif dan sebagai edukasi bagi siswa. Hal ini ditunjukkan pada gambar 2 dan 3.
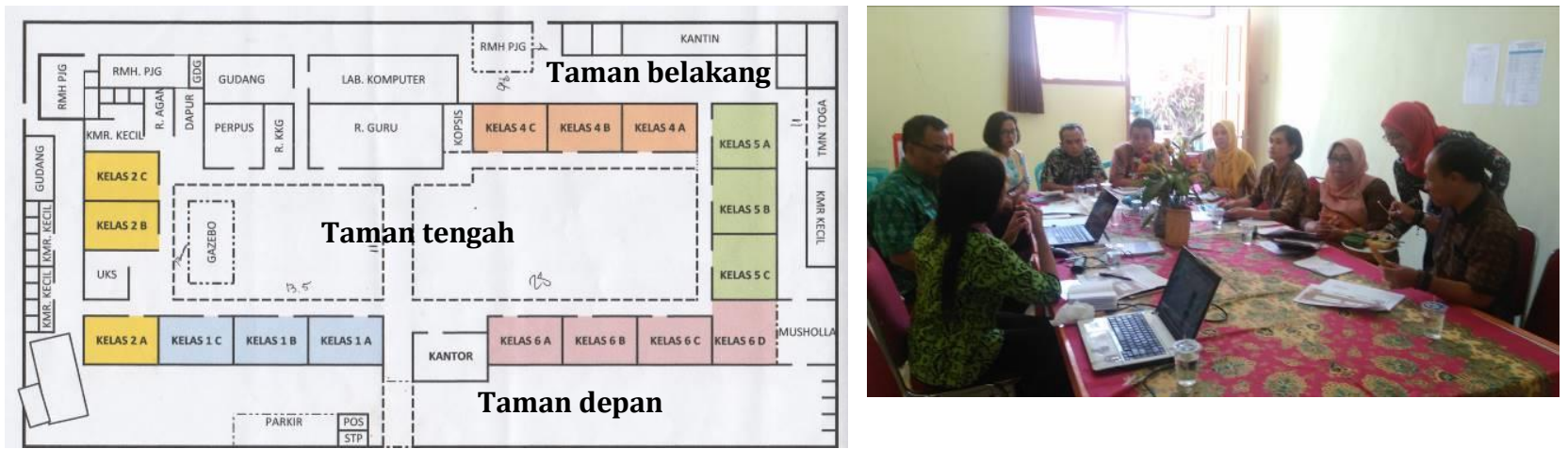

Gambar 2. (kiri) Denah Sekolah, dan (kanan) FGD dengan Komite Sekolah
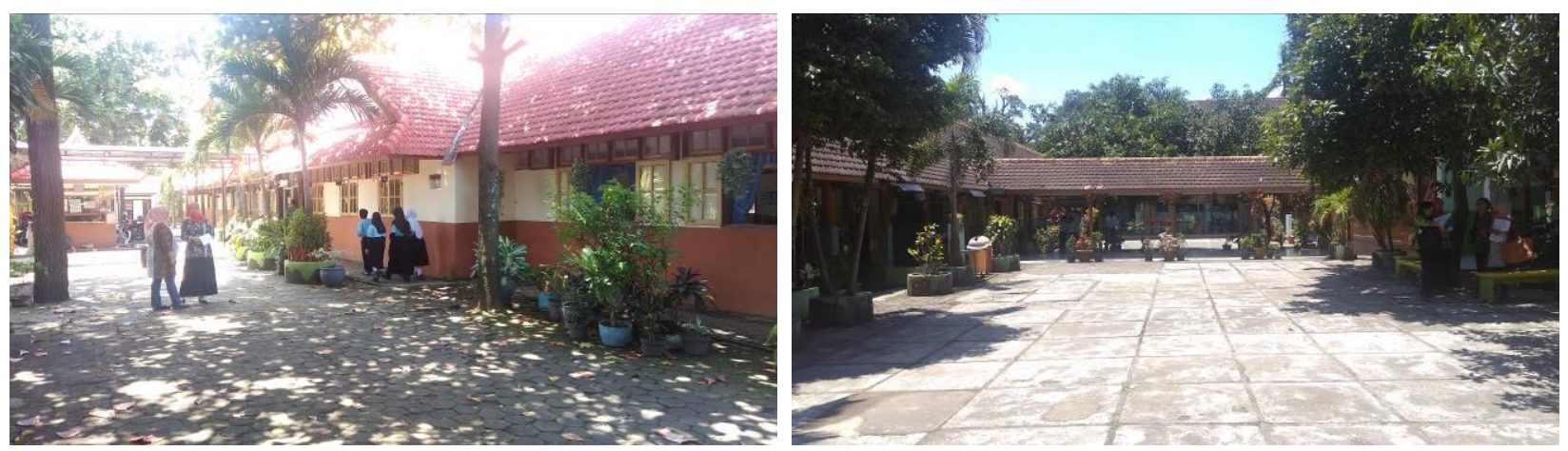

Gambar 3. (kiri) Taman Depan, dan (kanan) Taman Tengah

(sumber: dokumentasi)

\section{b. Analisis dan Sintesis Tapak}

Tapak sebagai lokasi desain perlu dikaji permasalahannya. Deskripsi ini memudahkan arsitek untuk memahami potensi, kendala dan menemukan tanggapan untuk mentukan kebutuhan dan fungsi. Adapun analisis-sintesis tapak yang ditampilkan hanya yang paling berpengaruh, yaitu vegetasi, sirkulasi, dan kebisingan. Vegetasi pada tapak sudah cukup bervariasi tetapi penataan kurang rapi diantaranya terdapat palem raja, ketapang, mangga, puring, gelombang cinta, dan sebagainya. Tanaman peneduh diperlukan di taman tengah karena masih kurang peneduh seperti ketapang atau 
mangga, tanaman hias diperlukan di area planter box seperti disusun bertingkat di area dekat jendela, tanaman gantung juga berisi tanaman hias seperti jenis anggrek yang jumlahnya masih kurang banyak, serta diperlukan tanaman vertikultur sebagai pemodelan untuk urban farming dan sarana edukasi siswa. Tanaman sebagai barrier kebisingan diperlukan di area depan dengan penitian dan merapatkan jumlah tanaman. Sirkulasi pada tapak, tidak ada batasan secara tegas, siswa bisa menjalankan aktivitasnya seperti berjalan, bermain, berlari secara bebas, namun demikian ada pergantian material yang awalnya beton rabat menjadi paving.

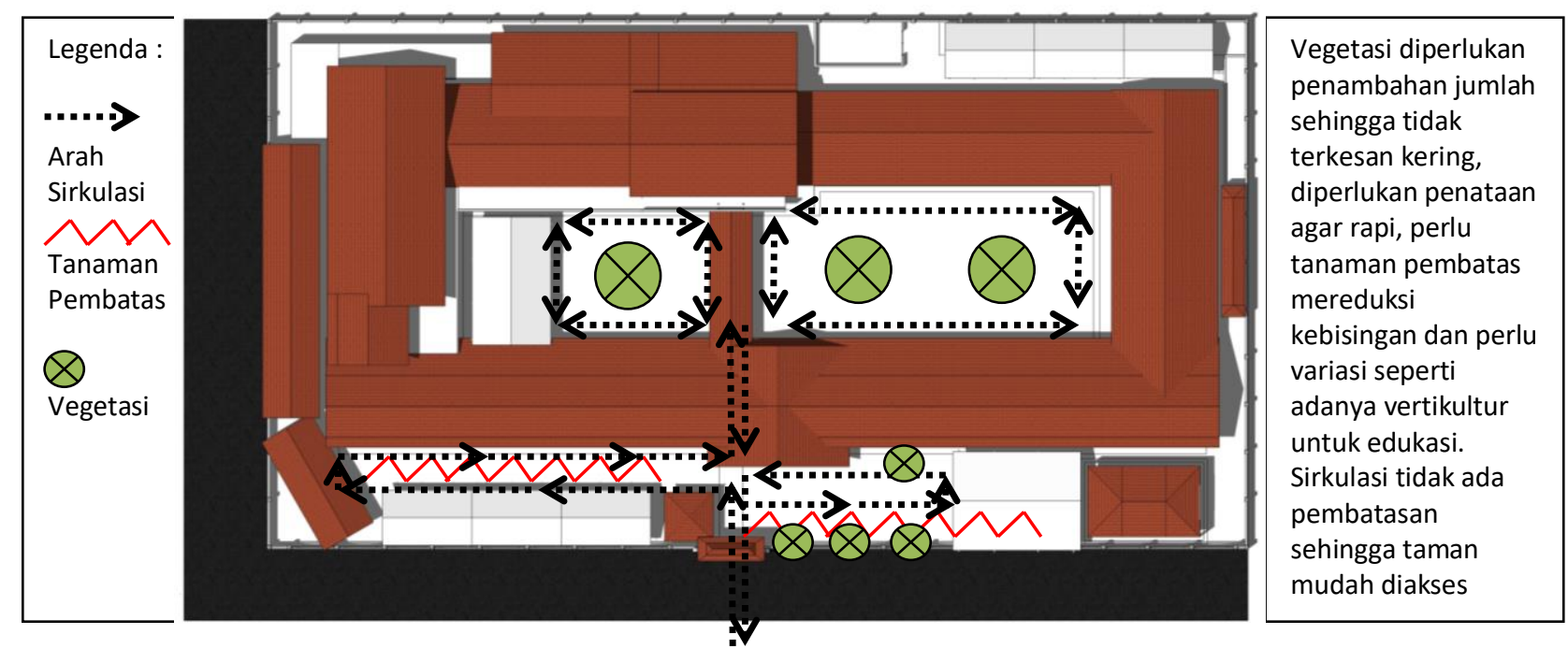

Gambar 4. Analisis dan Sintesis Tapak

c. Analisis Aktivitas, Fungsi, dan Ruang

Berdasarkan pengamatan di area tapak, ruang terbuka biasanya dipakai aktivitas pada jam-jam tertentu saja misalkan sebelum kelas dimulai (06.30), istirahat (08.3008.45 dan 10.30-11.00), dan pulang sekolah (13.00). Banyak diantaranya menghabiskan waktunya dengan duduk-duduk di bawah pohon peneduh taman tengah, makan bekal yang dibawa dari rumah, berlarian di taman tengah dan saling berinteraksi dengan teman-temannya.

Menurut Ibu Kun Aussieanita, selaku pengurus komite sekolah jenis aktivitas yang dilakukan di taman depan untuk kegiatan keagamaan karena terdapat masjid, yang melibatkan siswa sejumlah 600 orang. Taman tengah biasanya dipakai siswa untuk bersantai, duduk dan makan, sedangkan kegiatan formalnya yaitu lomba agustusan, potong tumpeng, latihan drumband, teater ataupun ekstra kurikuler. Kegiatan upacara dan olahraga tidak menggunakan taman depan atau taman tengah, tetapi ruang terbuka di depan sekolah. Untuk kegiatan edukasi yang melibatkan mata pelajaran tertentu di taman belum diterapkan. Eksistensi taman cukup penting karena dengan banyaknya tanaman dapat menjadikan lebih teduh, sejuk karena bisa sebagai penghasil oksigen, sehingga lebih nyaman. Selain itu bisa sebagai sarana edukasi untuk mengenalkan jenis tanaman dan cara perawatannya kepada siswa. Sebagai evaluasi keberadaan taman, ada program pemerintah berupa lomba lingkungan hidup atau green school festival sebagai media untuk identifikasi kekurangan taman, siswa dilibatkan untuk penyelesaian masalah. Utamanya, permasalahan yang terkesan kering, diperlukan biopori, perkerasan tidak ada resapan, variasi tanaman sudah cukup banyak tetapi belum ada penataan, sehingga diperlukan suatu rancangan taman nyaman untuk pengguna. Pentingnya taman di sekolah selain untuk mengikuti green school festival juga adanya program Adiwiyata, yaitu program pendidikan lingkungan hidup yang diprakarsai oleh Kementerian 
Lingkungan Hidup. Jadi, taman edukasi penting karena merupakan taman yang dapat memberikan pengayaan pada kurikulum sekolah dan berfungsi sebagai salah satu sarana menumbuhkan karakter cinta lingkungan, tanggung jawab dan bekerja sama.

Berdasarkan pengamatan dan wawancara tersebut diperlukan suatu ruang taman yang berfungsi mewadahi semua aktivitas. (1) Fungsi primer, sebagai sarana edukasi diperlukan area taman dengan jenis ragam tanaman (tanaman hias, toga, peneduh, pengarah dan pembatas) serta vertikultur untuk pembelajaran siswa (seperti ada penamaan tanaman dan pengenalan urban farming); area peneduh seperti pergola yang ada tanaman rambat diatasnya sehingga nyaman untuk duduk-duduk sambil membaca atau makan; dan area bermain yang mencakup fisik, kreatif, sosial, indera dan ketenangan. Ruang terbuka biasanya digunakan siswa bermain dengan berlari dan menjalin sosial dengan teman-temannya, kegiatan menggambar yang mengeksplorasi kreativitas, area duduk-duduk untuk mencari ketenangan (2) Fungsi sekunder yaitu fasilitas yang tidak harus ada namun penting seperti taman indera, area air mancur, taman gantung dengan sclupture, dan greenhouse.

\begin{tabular}{|l|l|l|l|l|}
\hline Primer & Sekunder & Area edukasi (ragam \\
tanaman dan & vertikultur) \\
2. & Area santai (pergola) \\
3. & $\begin{array}{l}\text { Area bermain } \\
\text { sederhana }\end{array}$
\end{tabular}

d. Zona Ruang

Gambar 5. Jenis Ruang

Zona ruang diperoleh dengan cara merangkai ruang-ruang berdasarkan tingkat kedekatan aksesnya. Hal ini merupakan alur cerita atau skenario pelaku aktivitas mulai masuk hingga keluar ruangan sebagai berikut.
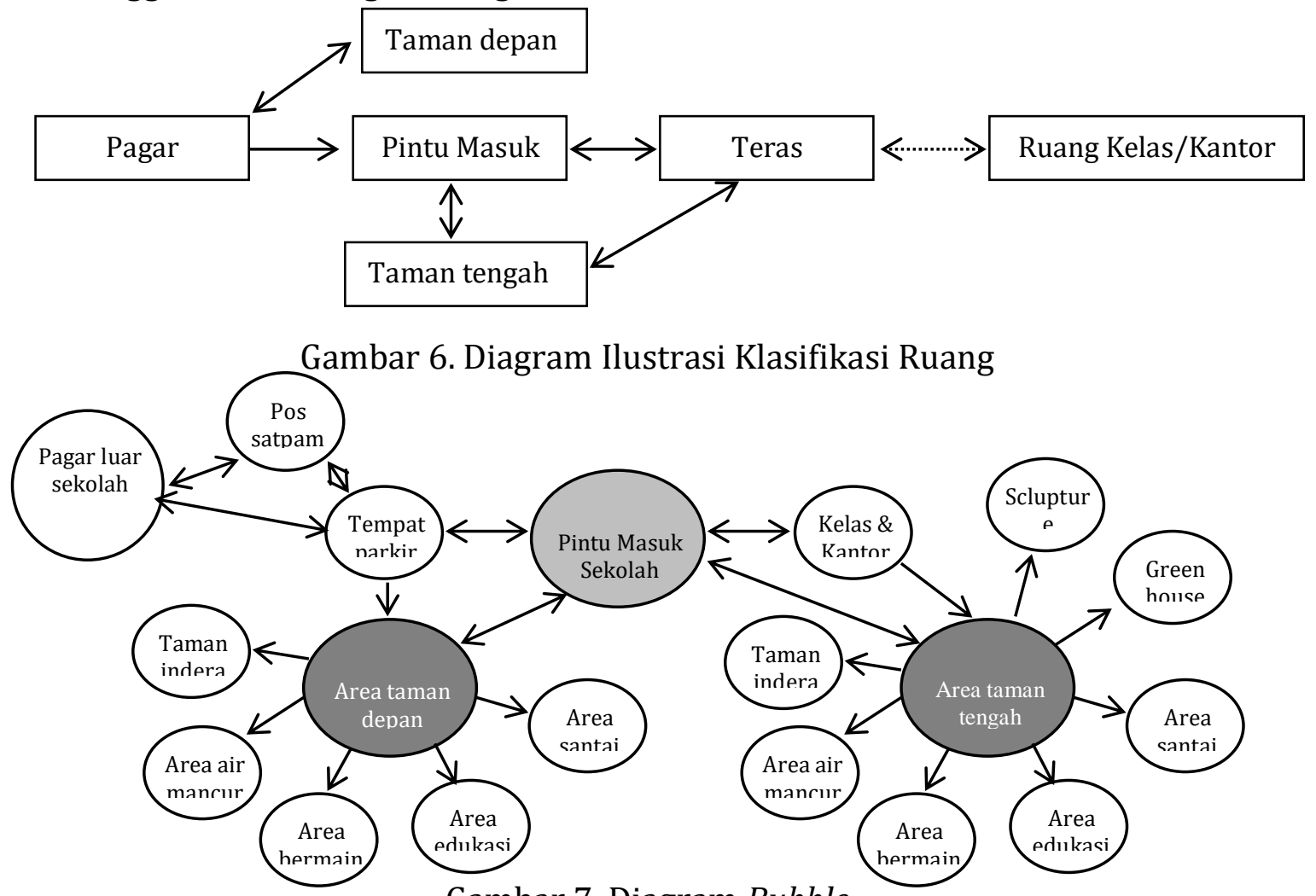

Gambar 7. Diagram Bubble 
Berdasarkan diagram kedekatan ruang (bubble) sebelumnya diketahui bahwa skenario taman berawal dari sirkulasi masuk tapak melalui pagar luar sekolah. Pengguna khusus warga sekolah seperti siswa dan guru, sedangkan orang tua atau penjemput hanya terbatas di taman depan. Setelah dari pos satpam dan tempat parkir, pengunjung bisa mengakses area taman depan, dimulai dari taman bunga di samping tempat parkir (area edukasi dan taman indera), sebagai edukasi karena mengenalkan jenis bunga dan sebagai taman indera yang merangsang aroma dan warna-warni bunga. Pengunjung juga bisa mengamati vertikultur di depan ruang komite. Setelah itu, diarahkan menuju ke pintu masuk utama melewati pohon palem sebagai pengarah dan ada susunan pot bunga bertingkat. Area sirkulasi sebagai area bermain aktif, siswa dapat berlari atau aktivitas lainnya. Sebelum menuju ke pintu masuk, pengunjung bisa meneruskan ke area taman depan masjid, yang terkadang untuk kegiatan keagamaan. Area ini terdapat tempat duduk sebagai area santai bisa dari kayu atau cor semen yang dibentuk alami, area edukasi hanya terdapat penamaan pada masing-masing pohon, selain itu juga terdapat area bermain. Air mancur hanya bersifat opsional saja.

Pengunjung bisa melewati pintu masuk utama untuk mengakses taman tengah yang terhubung dengan banyak ruangan seperti kantor dan ruang kelas. Untuk area terbuka masih dipertahankan taman disamping teras, hanya pemilihan dan penataan tanaman yang berubah. Awalnya taman hanya ruang terbuka bebas, sekarang ada pembagian zona yaitu (1) Taman edukasi terdiri atas: pengenalan jenis tanaman dengan adanya penamaan pada tanaman tertentu (hias, hortikultura, toga dan peneduh), pengenalan urban farming (sayuran dengan model vertikultur), alfabet atau angka pada perkerasan. (2) Area santai: adanya tempat duduk dari kayu/beton di bawah pohon mangga, dan di bawah area pergola. Area ini untuk mencari ketenangan diri yang bisa ditambahkan air mancur. (3) Taman indera, untuk menstimulasi indera. Air mancur juga dapat menstimulasi indera pendengaran sehingga lebih menenangkan dan bersifat healing dari tekanan penerimaan pelajaran. Air mancur dan tanaman berbiji juga dapat menarik kehadiran burung dengan kicauannya. Indera penglihatan distimulasi dari warna-warna tanaman seperti hijau pada sayuran, merah pada tanaman bunga andong, ungu pada lavender, kuning pada tabebuya, dan warna lain pada bunga. Indera penciuman bisa distimulasi dengan aromatik bunga, sedangkan indera peraba dengan tekstur material pada perkerasan. (4) Taman bermain berupa ruang terbuka saja yang tidak diperlukan pembagian zona secara tegas, satu area namun bisa untuk bermacam aktivitas seperti berjalan, berlari, bersosisalisasi dengan teman, dan menggambar. Adapun tambahannya berupa sclupture untuk taman gantung dan areenhouse hanva bersifat onsional.

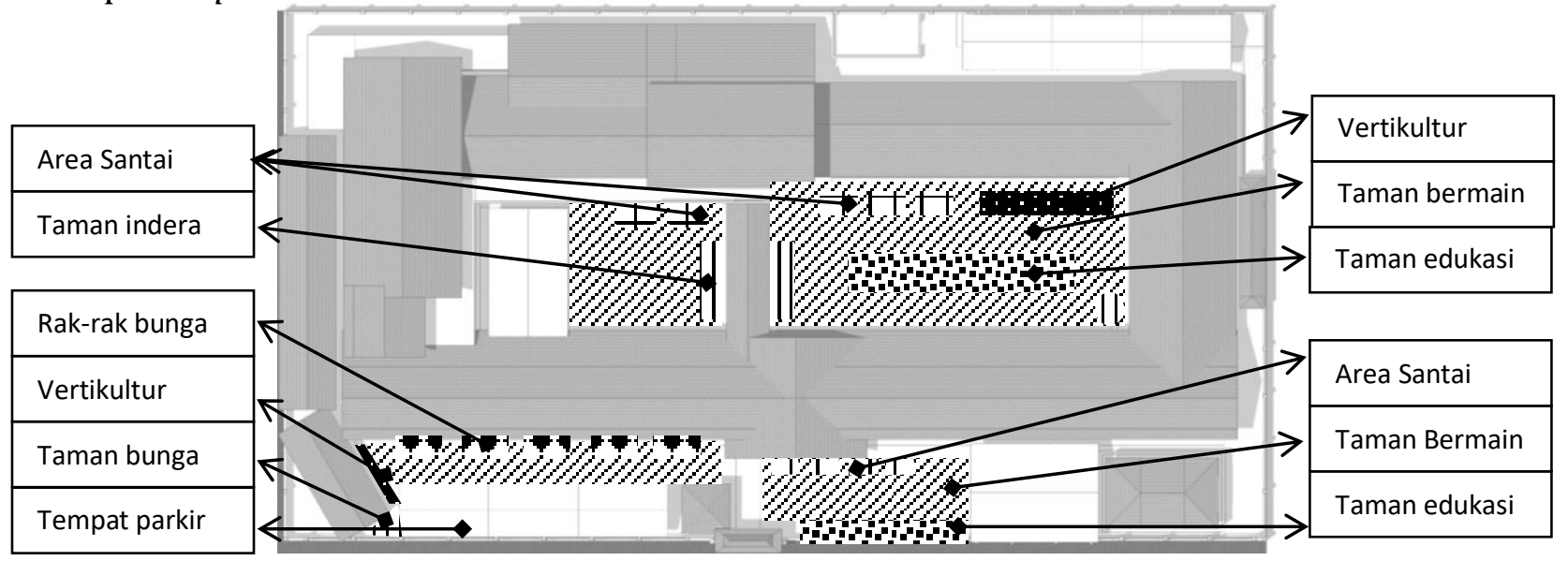

Gambar 8. Zonasi Pembagian Ruang 


\section{e. Konsep Dasar}

Dasar pemikiran pada taman ini adalah untuk edukasi. Penggunaan elemen keras dari material alam atau analogi bentukan menyerupai alam sehingga tidak terkesan kaku baik pada jalur sirkulasi, planter, tempat duduk, dan sebagainya. Sedangkan analogi penataan tanaman banyak dengan pola lengkungan atau sesuai kebutuhan.

(1) Konsep Bentuk

Bentukan rancangan diambil secara pragmatis atau skala disesuaikan dengan ukuran di lapangan, seperti halnya taman bunga, vertikultur, susunan pot bertingkat, area tempat duduk, taman edukasi, taman indera, dan taman bermain, pada gambar berikut.
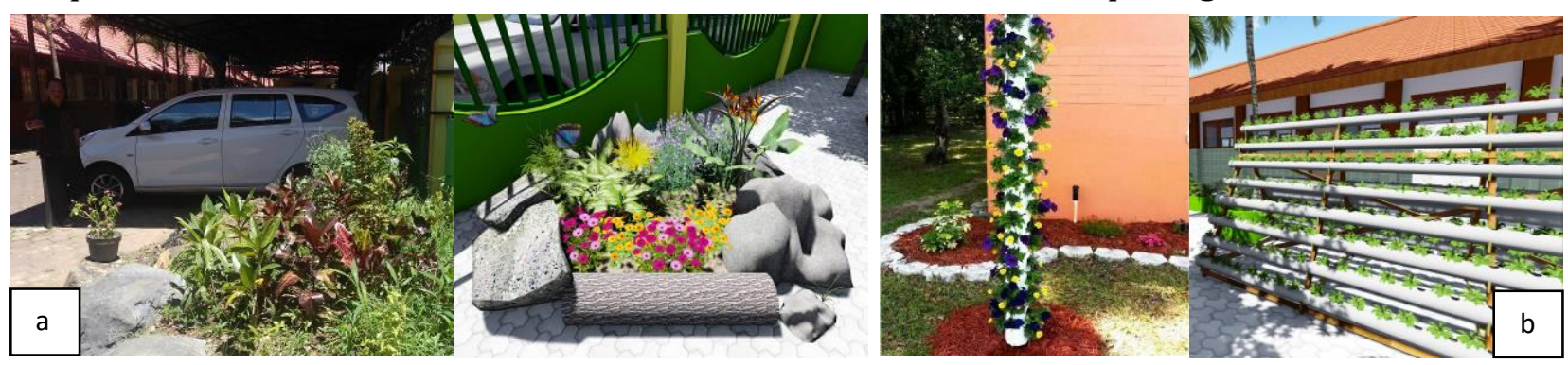

Gambar 9. (a) Eksisting dan Rencana Penataan Taman Bunga, (b) Model Vertikultur
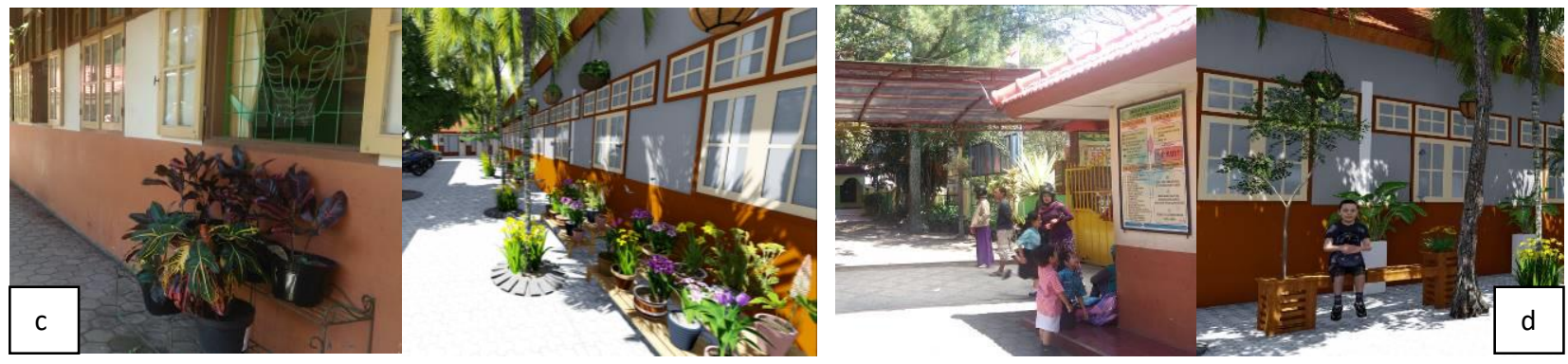

Gambar 10. (c) Eksisting Taman Rak, dan Rencana Penambahan Jumlah untuk Mencegah Penjemput ke Arah Jendela, (d) Penyediaan Tempat Duduk di Taman Depan
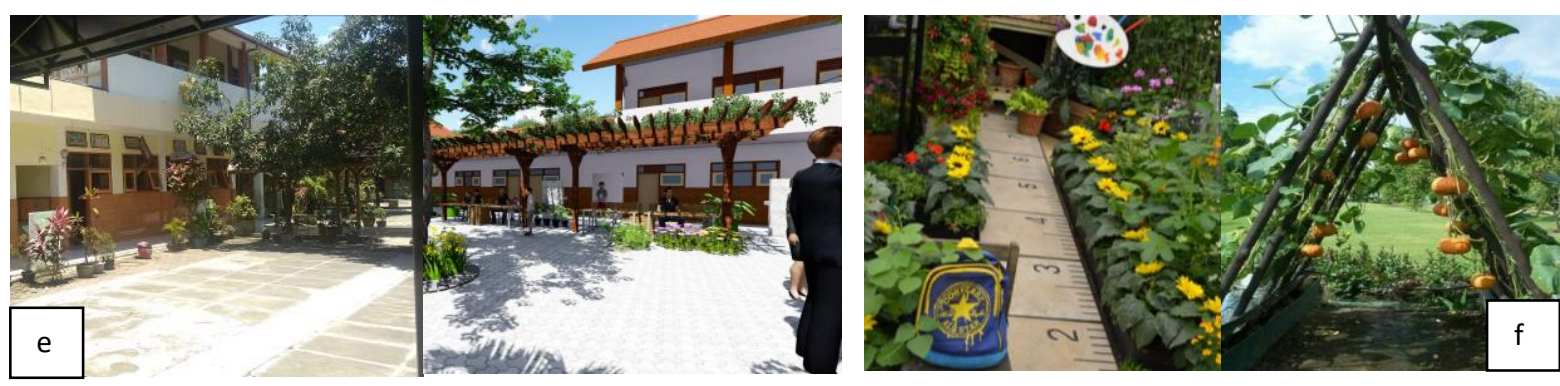

Gambar 11. (e) Eksisting dan Rencana Tempat Duduk dan Pergola Taman Tengah, (f) Model Taman Edukasi
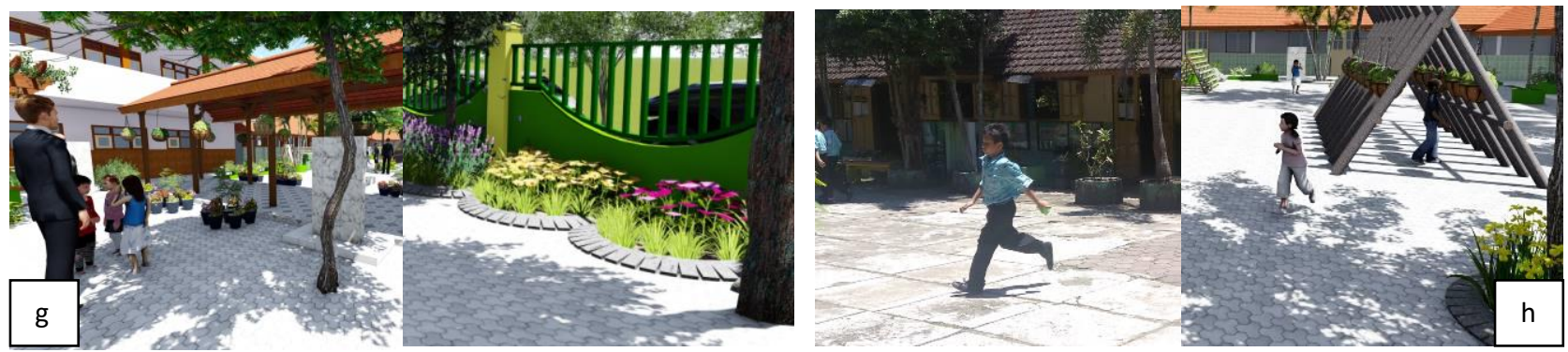

Gambar 12. (g) Model Taman Indera dengan Stimulus Warna untuk Penglihatan

(h) Taman Bermain Tetap Disediakan dengan Ruang Terbuka Bebas 


\section{(2) Konsep sirkulasi}

Sirkulasi sebagai penghubung antar ruang, baik dari luar menuju ke taman depan, dan dari ruang kelas atau kantor menuju ke taman tengah. Sirkulasi ruang direncanakan secara bebas, sehingga setiap sudut ruang bisa diakses. Namun tetap ada ruang pembatas agar masih terkesan diarahkan.

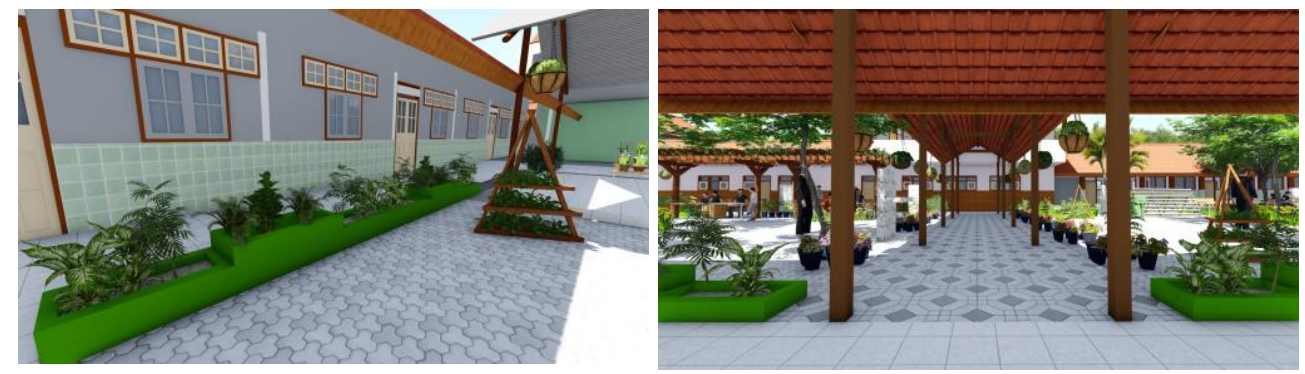

Gambar 13. (kiri) Setiap Sirkulasi di Depan Ruang Kelas Dibatasi oleh Planter, (kanan) Sirkulasi Penghubung Menuju ke Taman

(3) Konsep vegetasi

Vegetasi yang digunakan pada taman edukasi ini memiliki kriteria yaitu aman (tidak berduri dan tidak beracun), sedikit perawatan, tanaman berwarna/beraroma (taman bermain), tanaman yang menghasilkan (taman edukasi). Selain itu juga ada vegetasi yang dilihat dari fungsinya sebagai peneduh, pengarah, pembatas, dan estetika. Berikut merupakan tanaman terpilih 1) Tanaman Peneduh: Ketapang (Terminalia cattapa), Tabebuya (Tabebuia rosea), (2) Tanaman Pembatas: Penitian (Acalipa simaea), (3) Tanaman Pengarah: Palem Raja (Roystonea regia), (3) Tanaman Penghasil Pangan: Selada Air (Nasturtium officinale), Sawi (Brassica juncea L), Selederi (Apium graveolens L), dan tanaman estetika: Balanceng (Dieffenbacia), Bunga tasbih (Canna sp), Ruelia tegak (Ruellia), Alang putih (Ophiopogon Jab), Taberna hijau (Tabernae M.), Lili air mancur (Hymenocalis sp), Bakung (Crinum sp), Biola cantik (Ficus pandurata), Dadap merah (Erytrina c.), Phio daun kecil (Philo sp), Pacing pentul (Costus w), Krokot merah (Portulaca villosa Cham), Sirih gading (Scindapsus $s p$ ), Lidah mertua (Sansieverra), Iris (Neomarica longifoli), Bromelia (Bromelia sp), Wali songo (Muraya p.), Gardenia mini (Gardenis Sp), Melati air (Echinodoruss sp), Bambu air (Equisetum sp), Lotus (Nelumbo N.), Air Mata pengantin (Antigonon L.), Bauhinia (Bauhinia coccinea).

Adapun kriteria taman edukasi berikut merupakan uraian konsep yang didapatkan dari studi di atas untuk menambahkan pendapat dari Mandagi (2013) dan didukung oleh pemikiran dari Baskara (2011), Lauren (2012), Ramadhani (2016), dan Azra (2013), adalah sebagai berikut:

a. Tata ruang dibedakan menjadi fungsi primer yaitu taman edukasi, area tempat duduk dengan naungan (pergola), dan area bermain. Fungsi sekunder seperti taman indera, area healing (air mancur), taman gantung dan greenhouse.

b. Ruang edukasi, berperan untuk kegiatan pasif dan aktif. Kegiatan pasif seperti berjalan dan mengamati jenis tanaman. Kegiatan aktif yaitu melibatkan siswa untuk studi di luar ruang kelas (outdoor learning process), seperti ikut menanam, menjaga dan merawat tanaman untuk pengayaan pengalaman.

c. Ruang bermain, meliputi permainan fisik, kreatif, sosial dan indera dalam satu ruang tanpa pembatas yang tegas. Hal ini disebabkan sirkulasi direncanakan bebas dan mudah diakses, pembatas hanya berupa tanaman yang bersifat mengarahkan menuju ke ruang tertentu. 
d. Urban farming pada pekarangan, dengan adanya isu keterbatasan lahan akhirakhir ini, siswa dapat diberikan pemahaman agar penanaman tidak hanya diberlakukan secara horizontal. Dengan sistem baru yaitu vertikultur, tanaman dapat dikembangkan secara vertikal dengan pilihan tanaman yang produktif seperti sayuran.

e. Penggunaan ruang terbuka sebagai taman edukasi dapat menurunkan tekanan psikologis siswa oleh karena menerima pelajaran secara formal, sehingga taman edukasi memiliki fungsi sebagai taman rekreatif.

\section{Simpulan}

Peranan lingkungan bagi anak-anak adalah sebagai ruang bermain dan belajar, berlaku pula pada pekarangan sekolah. Oleh sebab itu peranan rancangan taman di sekolah ini bertindak sebagai pembelajaran nonformal ataupun formal. Dikatakan nonformal, siswa dapat belajar sendiri mengenai jenis vegetasi baik tanaman hias, sayur, toga ataupun bentuk vertikultur, secara mandiri, sedangkan pembelajaran formal ketika guru memasukkan unsur Outdoor Learning Process pada mata pelajaran tertentu. Selain itu dapat membangun edukasi secara fisik, mental, dan kreativitas melalui indera pendengaran, penglihatan, penciuman dan peraba. Edukasi tentang pelestarian lingkungan dapat dikombinasikan dengan permainan anak. Penggunaan material baik hardscape maupun softscape dipertimbangkan sisi keamanannya terhadap siswa sehingga tidak memberikan kecemasan ketika bermain. Hal tersebut merupakan konsep taman edukasi yang diterapkan pada SD Lowokwaru 3 sebagai tindak lanjut dari diskusi grup dan dapat menjadi acuan rancangan taman pada sekolah dasar lainnya.

\section{Ucapan Terima Kasih}

Puja dan puji syukur kami panjatkan kepada Tuhan Yang Maha Esa yang telah memberikan kelancaran pada kegiatan penelitian ini. Begitupula rasa terima kasih kami ucapkan kepada dekan fakultas pertanian, jajaran dosen Arsitektur Lanskap Universitas Tribhuwana Tunggadewi, kemudian Bapak Tjipto Yhuwono, SPd, MMPd. Selaku kepala sekolah SDN. Lowokwaru 3 Malang, para guru, beserta anggota komite sekolah khususnya Ibu Kun Aussieanita sebagai narasumber wawancara, yang turut serta membantu terselesaikannya penelitian dan program pengabdian masyrakat ini.

\section{Daftar Pustaka}

Asikin, D., Handayani, RP., Mustikawati, T. (2016). Vertical Garden dan Hidroponik sebagai Elemen Arsitektural di Dalam dan di Luar Ruangan. Jurnal RUAS, 14 (1), pp. 34-42.

Azra, A.LZ. (2013). Manajemen Lanskap Pekarangan bagi Penganekaragaman Konsumsi Pangan Keluarga. (online). http://repository.ipb.ac.id/handle/123456789/65534. diakses 21 April 2017.

Baskara, M. (2011). Prinsip Pengendalian Perancangan Taman Bermain Anak di Ruang Publik. Jurnal Lanskap Indonesia, 3 (1), pp. 27-34.

Direktorat Jenderal Penataan Ruang Departemen Pekerjaan Umum. (2008). Peraturan Menteri Pekerjaan Umum No: 05/PRT/M/2008 tentang Pedoman Penyediaan dan Pemanfaatan Ruang Terbuka Hijau di Kawasan Perkotaan.

Gold, S.M. (1980). Recreation Planning and Design. New York (US): McGraw-Hill Book Companies, Inc. 
Hakim, R. (2012). Komponen Perancangan Arsitektur Lansekap: Prinsip-Unsur dan Aplikasi Desain. Jakarta: PT. Bumi Aksara.

Lauren, G.M. (2012). Desain Taman Lingkungan untuk Anak Usia Sekolah Dasar di Cluster Callysta Permata, Perumahan Permata Bintaro, Tangerang Selatan. (online) http://repository.ipb.ac.id/handle/123456789/61159. diakses 21 April 2017.

Mandagi, A.U.G. (2013). Perancangan Taman Edukasi Lingkungan untuk Anak-anak di Situ Cikaret, Kecamatan Cibinong, Kabupaten Bogor. (online). http://repository.ipb.ac.id/handle/123456789/66082. diakses 21 April 2017.

Ramadhani, W.S. (2016). Penerapan Pembelajaran Outdoor Learning Process (OLP) melalui Pemanfaatan Taman Sekolah sebagai Sumber Belajar Materi Klasifikasi Tumbuhan untuk Meningkatkan Hasil Belajar Siswa SMP. Jurnal Pendidikan Sains, 4 (3), pp. 1-7.

Setyabudi, I. (2016). Elemen dan Proses Desain Arsitektur Lanskap Taman Rumah Tinggal. Malang: Dream Litera. 